УДК 001.4:81’373.421:811.133.1+339.138

DOI https://doi.org/10.26661/2414-1135-2021-83-9

\title{
СИНОНІМІЧНІСТЬ ЯК ОДНА $З$ ХАРАКТЕРИСТИК ТЕРМІНОСИСТЕМИ МАРКЕТИНГОВОЇ ДІЯЛЬНОСТІ ФРАНЦУЗЬКОЇ МОВИ
}

\author{
Демчук Н. М. \\ кандидат філологічних наук, доиент, \\ дочент кафедри іноземних мов \\ Львівський торговельно-економічний університет \\ вул. Туган-Барановського, 10, Львів, Україна \\ orcid.org/0000-0002-3452-5492 \\ nathalie.demchuk@gmail.com
}

Ключові слова: підмова маркетингу, способи збагачення лексики, лексичний інструментарій, система термінів, процес синонімізації, дублетні пари.
Функціонування мови відбувається відповідно до участі в процесі комунікації різних лінгвосоціумів. Відтак сфера мовленнєвої діяльності людини та ії прагматичний складник на рівні слова сприяє виявленню внутрішніх закономірностей регулювання адекватного вибору й уживанню лексичної одиниці в типовій комунікативній професійній ситуації.

Семантика маркетингової діяльності вимагає створення власного лексичного інструментарію для забезпечення адекватної комунікації між підприємствами на ринку, виробником і споживачем. Терміни як елементи специфічної системи мають низку особливостей, які вказують на належність до неї. Це матеріально-структурна риса, що характеризує термін як мовний знак: слугує його матеріальною основою (субстанцією) i водночас $є$ одиницею номінації й частиною лексико-семантичної системи мови.

Підмова маркетингу має спільні ознаки зі звичайною мовою, однак, 3 іншого боку, відрізняється від неї, оскільки містить слова, спеціально визначені для забезпечення сфери маркетингової діяльності, власне терміни, та інші слова, які вносять точність і конкретність у формулювання маркетингових термінів.

Крім внутрішніх джерел збагачення лексики, діють також зовнішні чинники, 3-поміж яких - запозичення, що оптимально корелюють зі звичайною лексикою. Часто англійські, американські терміни функціонують паралельно з їх французькими еквівалентами в результаті проникнення мови franglais. Активізація автохтонних мовних засобів хоча й сприяє збагаченню новими словами і словосполученнями, однак призводить до утворення пасивного лексичного фонду, що збільшує кількість дублетних пар.

Синонімію вважають одним із найважливіших видів парадигматичних зв'язків. Зазвичай велика кількість синонімів наголошує на полісемічному характері терміносистеми та, на противагу класичній термінології, не $\epsilon$ бажаним явищем. Контекст як головний фактор у процесі синонімізації $\epsilon$ важливим чинником у формуванні словника термінів маркетингу; саме макроконтекст створює підстави віднести той чи інший термін до системи термінів, оскільки реалізація відтінків значення в конкретному мовному середовищі $є$ його природною функцією. 


\title{
SYNONYMITY AS ONE OF THE CHARACTERISTICS \\ OF THE TERMINOLOGICAL SYSTEM OF MARKETING ACTIVITY \\ IN THE FRENCH LANGUAGE
}

\author{
Demchuk N. M. \\ Candidate of Philological Sciences (Ph.D. in Philology), \\ Associate Professor at the Department of Foreign Languages \\ Lviv University of Trade and Economics \\ Tuhan-Baranovskyy str., 10, Lviv, Ukraine \\ orcid.org/0000-0002-3452-5492 \\ nathalie.demchuk@gmail.com
}

Key words: sublanguage of marketing, ways of vocabulary enrichment, lexical tools, system of terms, synonymization process, doublet pairs.

\begin{abstract}
The functioning of language occurs in conformity with the participation of different linguistic communities in the process of communication. Thus, the sphere of human speech activity and its pragmatic component at the level of words contribute to the identification of internal regularities of adequate choice and use of the lexical unit in a typical communicative professional situation. The semantics of marketing activity requires the formation of its lexical tools to ensure adequate communication between businesses in the market, the producer and consumer.

Terms as elements of a specific system have several features that indicate belonging to it. This is the material and structural feature that characterizes the term as a linguistic sign: it serves as its material basis and at the same time acts as a unit of nomination and part of the lexical and semantic system of language. The sublanguage of marketing has common features with ordinary language, however, on the other hand, differs from it because it contains the words specifically designated for the sphere of marketing activity, the proper terms, and other lexemes that bring accuracy and specificity to the formulation of marketing terms.

In addition to internal sources of vocabulary enrichment, there are also external factors, including borrowings that optimally correlate with the usual vocabulary. Often English, American terms function in parallel with their French equivalents as a result of penetration of Franglais. Although the activation of autochthonous language means contributes to the enrichment with new words and phrases, it leads to the formation of a passive lexical fund, which increases the number of doublet pairs.

Synonymity is considered to be one of the most important types of paradigmatic relations. Usually, a large number of synonyms emphasize the polysemous nature of the terminological system and, in contrast to classical terminology, is not a desirable phenomenon. Context as the main factor in the process of synonymization is an important factor in the formation of the vocabulary of marketing terms; it is the macrocontext that creates grounds for attributing a term to a system of terms, since the realization of shades of meaning in a particular language environment is its natural function.
\end{abstract}

Постановка проблеми. Поява нових дисциплін на перетині вже наявних із подальшою генерацією відповідних підмов сприяє створенню нових понять, смислів, а також удосконаленню значення вже створених. Термінологічна лексика французької мови безпосередньо реагує на зміни об'єктивної реальності й відіграє головну роль у процесі науково-професійної комунікації (В.В. Виноградов, M.-Н. Гарі-Прієр). Характеристика структури й семантики терміносистеми маркетингової діяльності (далі - МД) відносить маркетинг до галузевих терміносистем із певним чином організованою системою знаків, яка номінує сукупність концептів конкретного фрагменту мовної картини світу.

Мета й завдання статті - визначити поняттєво-лексичний інструментарій терміносистеми маркетингової діяльності для їі подальшої характеристики. 
Об'єктом дослідження $є$ лексика маркетингової діяльності, досліджена у сферах фіксації та функціонування.

Предмет дослідження становлять дериваційні й таксономічної параметри організації терміносистеми маркетингової діяльності французької мови на основі іiі функціональних і лінгвокогнітивних ознак.

У роботі ми поділяємо позицію відомих лінгвістів: М.-К. Ломм, А. Леманн, Ф. Мартін-Берте, В. Виноградова, Д. Лотте, В. Лейчика та інших.

Наші попередні дослідження засвідчують, що терміни МД утворені за участю семантичного, синтаксичного, морфологічного, морфо-синтаксичного способів. Як відомо, за допомогою семантичного способу відбувається не лише термінологізація звичайних слів, а й переосмислюються одиниці спеціалізованої лексики 3 інших галузей науки. Синтаксичне термінотворення проявляється найяскравіше в застосуванні англіцизмів, що підкреслює вчергове інтернаціональний характер термінів і їх роль у міжнародній стандартизації та уніфікації науково-технічної термінології. У процесі словотворення деривація за допомогою афіксальних морфем $\epsilon$ найпродуктивнішою. Для морфо-синтаксичного способу характерна модель $N+$ abréviation (іменник + абревіатура), за якою утворюють нові номінативні одиниці з прозорою словотвірною структурою і вмотивованим значенням.

Виклад основного матеріалу дослідження.

Роль слів-субституентів у мові. Мова науки з іiї тенденцією до однозначності не може уникнути проявів різноманітності, оскільки є складником загальнонаціональної мови. На думку Ф. де Соссюра, уривок тексту, який не містить синонімів, $є$ не просто одноманітним: його мова створює враження патологічного мовлення [11, p. 24-36].

Явище номінащіï. Відзначаючи можливість і здатність предмета мати дві, три й більше назв, B.M. Лейчик указує на причини цього явища, а саме складність самого предмета, виявлення його нових ознак і властивостей у процесі розвитку суспільства, різні точки зору на цей предмет. 3 огляду на це, виникають різні види подвійної (потрійної) номінації. Складний, багатогранний предмет може за потреби позначатися водночас двома назвами навіть в одному реченні, такий вид номінації лінгвіст називає одночасною мовленнєвою номінацією [3, с. 99-103]. Відтак одночасну номінацію спостерігаємо при повторному вживанні в тексті одного й того самого слова чи терміна, наприклад: La Citroën C3 Pluriel peut être décrite par un ensemble de caractéristiques techniques et commerciales, comme toutes les voitures actuellement sur le marché (longueur, largeur, hauteur, motorisation). Mais son positionnement vient de quelques caractéristiques véritablement distinctives par rapport aux autres automobiles: modularité très importante par rapport aux dimensions du véhicule, organisation intérieure etc/Citroën C3 Pluriel можна описати за допомогою технічних і комерційних характеристик, як і всі автомобілі на сучасному ринку (довжина, ширина, висота, механічні дані). Однак для його позиціонування достатньо кілька критеріїв, які вирізняють цей автомобіль 3-поміж інших: високий рівень модульності щодо розмірів транспортного засобу, внутрішня організація тощо [7, p. 101]. Лексеми voiture, automobile, véhicule в наведеному уривку позначають той самий предмет - авто марки Citroën C3 Pluriel.

Типи синонімів у французькій мові. Аналіз лексики свідчить про наявність двох типів синонімів у французькій терміносистемі маркетингу: морфологічних (варіантних) і лексичних.

Морфологічна синонімія $є$ водночас показником динамізму і стійкості морфології, тобто у випадку стабільності певного функціонального типу лексеми в ній можуть відбуватися внутрішні зміни й переміщення: зменшення або збільшення кількості морфем свідчить про морфологічні зрушення в мові та перенесення центру ваги з одного варіанта на інший [8, p. 54-57]: emballage (m) заміняється неологізмом embellage (m)/захисне упакування товару; consommatisme $(\mathrm{m})=$ consommaction (f) = consommérisme (m)/організація із захисту прав споживачів [10]. До того ж частотність моделі не завжди збігається з її продуктивністю, ці два поняття не варто ототожнювати.

Найбільш представленою в підмові маркетингу є лексична синонімія, яка полягає у спільній семантичній сутності. Наприклад, magasinage $(\mathrm{m})=$ chalandage $(\mathrm{m})=$ lèche-vitrines (m) - pratique récréative consistant à découvrir différentes offres de produits, en vue d'un éventuel achat/розвага задля вивчення пропозиції товару 3 метою придбання [10].

У мові зустрічаються так звані нюанси значень термінів, які маркують дещо різні смисли попри тотожність їх властивостей. Такий тип Д.С. Лотте називає відносними синонімами - коли смисли співпадають частково [4, с. 22]. Наприклад, терміни impôt $(\mathrm{m})$ - taxe, droit subvenus aux dépenses publiques/сума, стягнута при сплаті державних виплат, синонімами якого $\epsilon$ droit $(\mathrm{m})$ i taxe (f)/сплата, податок, уважають абсолютними синонімами, що означають «податок», тоді як подібні за своєю сутністю contribution (f) - part payée par chacun dans une dépense/частка, яку сплачує кожен у загальній сумі витрати, cotisation (f) - somme pour couvrir une dépenses commune/сума на погашення загальної витрати, поряд із prélèvement (m) règlement automatique d'une somme/автоматичне стягнення певної суми, redevance (f) - somme 
versée à échéances déterminées/сума, яку погашають у визначений термін, - відносними, оскільки ïх лише ототожнюють із погашенням суми боргу, суть виплати якого дещо відрізняється [6].

Стилістична синонімія включає функціональні синоніми, які вирізняються стилістично (directeur artistique $=$ chef décorateur $=$ concepteur graphique/головний дизайнер) та експресивно-смислові синоніми, які, на думку лінгвіста, різняться додатковими конотаціями: consommateur (m) «споживач» та utilisateur final «кінцевий користувач» [10]. Уважаємо, що багаторазове використання терміна в типовій професійній комунікації викликає узуальне закріплення в ньому інформації функціонального характеру. Під час аналізу синонімічних засобів вираження беремо до уваги позицію В.В. Виноградова стосовно ідеографічної синонімії, яка полягає в диференціації смислових відтінків [1, с. 3-10].

А. Леманн, Ф. Мартін-Берте визначають синонімію як відношення еквівалентності між двома чи кількома лексичними одиницями з різною формою. Зазвичай синонімам характерна наявність одного позначуваного (même signifié) і кількох позначувальних (signifiants différents): у цьому сенсі вони $є$ повною протилежністю омонімів, для яких характерне одне позначувальне й різні позначувані [7, p. 54-55].

На переконання Ж. Філіоле, Ж.-Л. Шісса, Д. Менгено, в ідеалі синонімія мала б зводитися до взаємозамінюваності двох лексичних одиниць-синонімів у всіх контекстах. Згідно 3 мовною традицією, абсолютних синонімів не існує: найменший нюанс завжди вирізняє навіть так званий «сумнівний» синонім [5, p. 130-131]

Канадійська дослідниця М.-К. Ломм розглядає синонімію як із семантичного, так і 3 концептуального погляду, уважає синонімами лише терміни 3 наявним спільним концептом. М.-К. Ломм зазначає, що класична термінологія все ж визнає наявність кількох термінів на позначення одного концепту - це випадки, коли терміни зберігають однакове значення в різних контекстах. Різниця, наприклад, полягає в тому, що mél затверджений як активний термін нормою у Франції, а courriel використовується у Квебеку [9, p. 95-96].

Опис форми і смислу, тобто синтаксис і семантика, ще не дають нам повного опису мови, оскільки мовні факти можна розглядати також 3 прагматичної точки зору, наприклад, залежності від контексту, який сприяє реалізації значення терміна й допомагає розпізнати точне значення й тип терміна, а також рівень його співвіднесеності 3 тою чи іншою галуззю науки чи техніки.

Роль прагматики у виборі синонімів. Зазвичай прагматичні компоненти супроводжують семантичні на всіх етапах формування семантичного потенціалу мовного знаку. Такі прагматичні характеристики, як оцінність, експресивність, емотивність тощо, можуть бути зафіксовані поряд 3 денотативною інформацією в лексичних одиницях або ж у формах граматичних категорій. Приклади, узяті зі щотижневика Courrier international (Les clients examinent les marchandises proposées par les commerçants ambulants/Клієнти розглядають товари, запропоновані «пересувними» торговцями; J'ai été victime d'une agression verbale pour avoir empêché un marchant ambulant d'exposer sa marchandise devant la boutique/Я став жертвою словесного нападу за те, що перешкодив «пересувному» торговцю продавати перед магазином; Ces vendeurs clandestins qui ne payent ni taxes ni loyer concurrencent les commerçants du circuit officiel/Ці нелегальні торговці, які не платять ані податків, ані за оренду, становлять конкуренцію офіційній торговій мережі [12], указують на те, що оцінний елемент терміна дає змогу визначити його ціннісне значення та відповідність стандартам, прийнятим у суспільстві, тобто висловлюють ставлення суспільства до вказаної категорії осіб: commerçants ambulants - «торговці, які продають дешевше товар» і vendeurs clandestins - «нелегальні торговці» - або явищ: vente sous le manteau (vente sauvage) - «дика», нелегальна торгівля.

Оскільки в мові слово не ізольоване, воно набуває змісту в тій чи іншій семантичній структурі, що й впливає на вибір синоніма. Окрім того, наявність значної кількості синонімів завдячує помітному вживанню англіцизмів серед окремих соціумів, що пояснюється стрімким розвитком технологій і зникненням кордонів у світі комунікацій у маркетингу в тому числі, $є$ досить поширеним явищем: now-how = savoir-faire $(\mathrm{m}) /$ навичка, shopping = magasinage $(\mathrm{m}) /$ покупки, package = emballage $(\mathrm{m}) /$ пакування. Однією з причин пошуку англійських термінів на позначення понять у французькій мові $\epsilon$ їх містка структура, що слугує мовній економії: англ. multipack «мультипакування» на заміну франц. emballage groupé; англ. corner «місце під рекламу товару» замість франц. emplacement promotionnel [10]. Ці синоніми покликані для уточнення або диференціації значень чи їх відтінків, оскільки саме прагматичний компонент у семантичній структурі слова $\epsilon$ тією ланкою, яка поєднує семантику слова 3 його прагматикою. 3 іншого боку, оскільки значна частина термінів має інтернаціональний характер, то їх розуміння та дефініція, 3 огляду на контекст, не створюють труднощів, однак цей складний процес ще потребує подальшої уваги лінгвістів. Отже, дослідження терміносистеми МД виявило немалу кількість синонімів (таблиця 1). 
Таблиця 1

\section{Синонімічні терміни маркетингу}

\begin{tabular}{|c|c|c|}
\hline & Термін & Синоніми \\
\hline 1 & Achat plaisir - купівля заради задоволення & $\begin{array}{l}\text { magasinage }(\mathrm{m}) \text {, achat récréatif, } \\
\text { mercatique expérientielle }\end{array}$ \\
\hline 2 & Badge antivol - бедж-захист від крадіжки & $\begin{array}{l}\text { étiquette rigide, galette }(\mathrm{f}), \text { macaron }(\mathrm{m}), \\
\text { traceur }(\mathrm{m}) \text {, verrou antivol }\end{array}$ \\
\hline 3 & Bail (m) - договір оренди & contrat de location \\
\hline 4 & Bannière publicitaire - рекламний банер & bandeau publicitaire \\
\hline 5 & Bénéfice (f) - прибуток & profit (m) \\
\hline 6 & Bon prime - картка на знижку & $\begin{array}{l}\text { bon cadeau, timbre de fidélité, } \\
\text { timbre prime, timbre ristourne }\end{array}$ \\
\hline 7 & Brochure publicitaire - рекламний матеріал & $\begin{array}{l}\text { dépliant publicitaire, } \\
\text { plaquette publicitaire }\end{array}$ \\
\hline 8 & Clientèle (f) - клієнти & achalandage $(\mathrm{m})$, chalandise $(\mathrm{f})$ \\
\hline 9. & Chef de département - начальник відділу & $\begin{array}{l}\text { responsable de secteur } \\
\text { directeur de la commercialisation }\end{array}$ \\
\hline 10 & Chèque restaurant - картка на знижку в ресторані & $\begin{array}{l}\text { ticket restaurant, titre restaurant, } \\
\text { chèque-repas, chèque déjeuner }\end{array}$ \\
\hline 11 & Club entrepôt - магазин-склад & libre-service de gros, magasin entrepôt \\
\hline 12 & $\begin{array}{l}\text { Addition (f) - рахунок на оплату в закладі } \\
\text { харчування }\end{array}$ & note $(\mathrm{f})$, total $(\mathrm{m})$ \\
\hline 13 & Consommateur (m) - споживач & utilisateur final \\
\hline 14 & Emballer (v) - запакувати & empaqueter, conditionner, envelopper \\
\hline 15 & Emblème de marque - лого марки & logotype, signe visuel \\
\hline 16 & Entreposer (v) - помістити на склад & emmagasiner, stocker \\
\hline 17 & Impôt $(\mathrm{m})$ - податок & $\begin{array}{l}\text { contribution }(\mathrm{f}) \text {, cotisation }(\mathrm{f}), \\
\text { droit }(\mathrm{m}), \text { prélèvement }(\mathrm{m}), \\
\text { redevance }(\mathrm{f}), \text { taxe }(\mathrm{f})\end{array}$ \\
\hline 18 & Lecteur optique - зчитувач штрих-коду & $\begin{array}{l}\text { douchette }(\mathrm{f}), \text { lecteur de code barres, } \\
\text { peigne optique, scanneur }(\mathrm{m}) \text {, scannette }(\mathrm{f})\end{array}$ \\
\hline 19 & $\begin{array}{l}\text { Prescripteur }(\mathrm{m}) \text { - особа, що впливає на } \\
\text { здійснення покупки }\end{array}$ & $\begin{array}{l}\text { incitateur }(\mathrm{m}) \text {, influenceur }(\mathrm{m}), \\
\text { préconisateur }(\mathrm{m})\end{array}$ \\
\hline 20 & Prospect (m) - потенційний клієнт & client potentiel, client effectif \\
\hline 21 & Rabais $(\mathrm{m})$ - знижка & réduction $(\mathrm{f})$, remise $(\mathrm{f})$, ristourne $(\mathrm{f})$ \\
\hline 22 & Vendeur (m) - продавець & conseiller de clientèle, chargé de clientèle \\
\hline
\end{tabular}

У лінгвістиці вважають, що контекст допомагає слову чи терміну виступати в значенні, яке створює основу для так званої виразності мови [2, с. 107$]$.

Висновки й перспективи подалыших доробок. Неможливість чіткого дотримання законів термінотворення призводить до надмірної синонімії, що, безперечно, шкодить термінологічній точності. Синонімія безпосередньо пов'язана 3 проблемою відбору та компетентного використання термінологічних одиниць 3-поміж паралельних фахових найменувань, що є закономірним наслідком термінологічного впорядкування.

Установлено часте функціонування англійських, американських термінів паралельно 3 їх французькими еквівалентами: autophoning = télévente automatique; blister = emballage-coque; broker = courtier, що відбувається в результаті проникнення мови «franglais». Активізація автохтон- них мовних засобів сприяє збагаченню новими словами і словосполученнями, однак призводить до утворення пасивного лексичного фонду, що збільшує в мовленні кількість дублетних пар.

Підсумовуючи дослідження, зазначимо, що в маркетингу лише невелика кількість синонімічних пар може взаємозамінюватися, що вказує на їх «неідеальність» із концептуальної позиції. Саме в мікроконтексті, у якому розшифрування слова відбувається через непрямі семантичні зв'язки, виокремлюють різновиди синонімів: 3-поміж великої кількості смислів слова реалізується один, який в іншому контексті $є$ близьким або дорівнює іншому значенню, зафіксованому узусом i, відповідно, словником. У цьому випадку йдеться про явище квазісинонімії. До того ж різниця між синонімами не проявляється в концептуальному : вона зумовлена зовнішніми чинниками, 
зокрема рівнем мовлення, географічними, соціолінгвістичними змінами тощо. Саме ономасіологічний аспект нас цікавить у плані подальшого дослідження, де концепт є головним критерієм вибору слова, групи слів чи виразів, які використовуються для його позначення.

\section{ЛІТЕРАТУРА}

1. Виноградов В.В. Вступительное слово. Bопросы терминологии. Москва, 1961. C. 3-10.

2. Колшанский Г.В. Коммуникативная функция и структура языка. Москва : Наука, 1984. $174 \mathrm{c}$.

3. Лотте Д.С. Основы построения научно-технической терминологии. Boпросы теории $u$ методики. Москва : АН СССР, 1961. С. 22.

4. Люди и слова / В.М. Лейчик и др. Москва : Наука, 1982. С. 99-103.

5. Chiss J.-L. Introduction à la linguistique française. Syntaxe, communication, poétique. Paris : Hachette, 2001. T. 2. P. 130-131.

6. Delamarche C. Dictionnaire de la langue français. Paris : Hachette, 1994.

7. Demeure C. Marketing. Aide-memoire. 6-e ed. Paris : Dunod, 2008.

8. Lehmann A., Martin-Bertlet F. Introduction à la lexicologie. Sémantique et morphologie. Paris : Nathan, 2000. P. 54-55.

9. L'homme M.-C. La terminologie: principles et techniques. Montréal : Les presses de l'Université de Montréal, 2008. P. 95-96.

10. Madry P. Dictionnaire pratique du commerce. Bruxelles : De boeck, 2009.
11. Saussure F. de. Cours de linguistique générale. Paris : Payot, 2005. P. 24-36.

12. Courrier International. Paris, 2015. № 1280. $1281 \mathrm{p}$.

\section{REFERENCES}

1. Vynogradov, V.V. (1961). Vstupitelnoje slovo. Voprosy terminologii. Moscow [in Russian].

2. Kolshanskyy, G.V. (1984). Komunikativnaya funkciya i struktura yazyka. Moscow : Nauka [in Russian].

3. Lotte, D.S.(1961). Osnovy postrojenija nautchnotekhnycheskoy terminologii. Voprosy teorii $i$ metodiki. Moscow: AN SSSR [in Russian].

4. Leychik. V.M. (Eds.). (1982). Lyudi i slova. Moscow: Nauka [in Russian].

5. Chiss J.-L. (2001) Introduction à la linguistique française. Syntaxe, communication, poétique. Paris: Hachette. T. 2.

6. Delamarche C. (1994) Dictionnaire de la langue français. Paris: Hachette.

7. Demeure C. (2008) Marketing. Aide-memoire [6-e ed.]. Paris: Dunod.

8. Lehmann A., Martin-Bertlet F. (2000) Introduction à la lexicologie. Sémantique et morphologie. Paris: Nathan.

9. L'homme M.-C. (2008) La terminologie: principles et techniques. Montréal: Les presses de l'Université de Montréal.

10. Madry P. (2009) Dictionnaire pratique $d u$ commerce. Bruxelles: De boeck.

11. Saussure F. de. (2005) Cours de linguistique générale. Paris: Payot.

12. Courrier International. Paris, 2015, no 1280, 1281. 